\title{
Assessment of Serum Uric Acid Levels According to Sex and Stage for Patients with Alzheimer-type Dementia
}

Alzheimer Tipi Demans Tanılı Hastalarda Cinsiyete ve Evrelere Göre Serum Ürik Asit Seviyelerinin Değerlendirilmesi

\author{
(1) Tamer Yazar ${ }^{1}$, (1) Hülya Olgun Yazar² \\ ${ }^{1}$ Ordu State Hospital, Clinic of Neurology, Ordu, Turkey \\ 2Ordu University Training and Research Hospital, Clinic of Neurology, Ordu, Turkey
}

\begin{abstract}
Objective: The aim of this study was to identify serum uric acid (UA) concentrations according to disease stage in patients with Alzheimer-type dementia (AD), and to collect data related to the hypothesis that oxidative stress is effective on the etiopathogenesis and progression of disease stage.

Materials and Methods: The study was conducted with 180 patients who were categorized into disease stages in accordance with the Clinical Dementia Rating Scale (CDR) and 150 healthy individuals of the same age group. In our retrospective study, patients who showed more than one cognitive deficit and diagnosed with possible AD according to the diagnostic criteria of National Institute of Neurological and Communicative Disorders and Stroke-Alzheimer's Disease and Related Disorders Association were administered the CDR, Mini-Mental Test (MMSE), Geriatric Depression Rating Scale (GDRS), and individuals in the control group were administered the MMSE and GDRS. Venous blood samples for biochemical studies were collected after 12-14 hours of fasting in the patient and control groups.

Results: In patients diagnosed as having $\mathrm{AD}$, it was found that there was a statistically significant increase in age and duration of disease parallel with the progression of disease stages, and a decrease in UA and albumin concentrations in both males and females $(\mathrm{p}<0.05)$.

Conclusion: Our study supports the hypothesis that the decrease detected in serum UA concentrations in parallel with the progression of disease stages is directly related to the pathogenesis of $\mathrm{AD}$.

For the identification of chronic progressive diseases such as AD and to take precautions, the identification of variations in easily accessible and low-cost parameters such as serum albumin and UA concentrations in the early stages becomes important. In future years, when neuroprotective and neuro-restorative treatment options are available, identification of serum UA values as a marker of disease progression and knowledge of the association between serum UA concentrations and disease stage in our data will guide and support research into disease etiology.
\end{abstract}

Keywords: Alzheimer disease, dementia, oxidative stress, uric acid, sex

Öz

Amaç: Alzheimer tipi demans (AH) tanılı hastalarda hastalık evresine göre serum ürik asit (ÜA) seviyelerinin tespiti ile oksidatif stresin hastalık etiyolojisindeki rolüne ve hastalık evresinin ilerlemesi üzerindeki olası etkilerine yönelik veriler toplanması amaçlanmıştır.

Gereç ve Yöntem: Çalı̧̧ma, Clinical Dementia Rating Scale (CDR) kriterlerine göre evrelere ayrılan 180 hasta ve hastalarla aynı yaş aralığında sağlıklı 150 birey ile gerçekleştirilmiştir. Retrospektif olarak yapılan çalışmamızda, birden fazla bilişsel alanda bozukluk gösteren ve National Institute of Neurological and Communicative Disorders and Stroke-Alzheimer's Disease and Related Disorders Association tanı kriterlerine göre olası AH tanısı konulmuş hastalara CDR, MiniMental Test (MMSE), Geriatrik Depresyon Rating Scale (GDRS), kontrol grubundaki bireylere MMSE ve GDRS uygulanmıştır. Hasta ve kontrol gruplarında 12-14 saat açlıktan sonra biyokimyasal çalışmalar için venöz kan örnekleri alınmıştır.

Bulgular: AH tanılılarda, hastalık evrelerindeki artışa paralel olarak kadın ve erkeklerde istatistiksel olarak anlamlı seviyede yaş ve hastalık sürelerinin arttı̆̆ı, ÜA ve albümin seviyelerinin azaldığ

Sonuç: Çalışmamız, ÜA'nın serum seviyelerindeki hastalık evrelerindeki ilerlemeye paralel olarak tespit edilen azalmanın AH ile doğrudan ilişkili olduğu hipotezini desteklemektedir. AH gibi kronik, ilerleyici hastalıkların başlangıç evrelerinde tespiti ve önlemler alınabilmesi için, serum albümin ve ÜA seviyesi gibi kolay ulaşılabilir, az maliyetli parametrelerdeki değişikliklerin erken dönemde tespiti, AH tanıs konulduktan sonra uygulanan tedavilerin hastalığı önleyici etkilerinin kısıtlılı̆̆

Anahtar Kelimeler: Alzheimer hastalı̆̆1, demans, oksidatif stres, ürik asit, cinsiyet

Address for Correspondence/Yazışma Adresi: Tamer Yazar MD, Ordu State Hospital, Clinic of Neurology, Ordu, Turkey

Phone: +90 5055927360 E-mail: tamer.yazar@yahoo.com.tr ORCID ID: orcid.org/0000-0003-3054-6613

Received/Geliş Tarihi: 24.08.2018 Accepted/Kabul Tarihi: 15.12.2018

${ }^{\circ}$ Copyright 2019 by Turkish Neurological Society

Turkish Journal of Neurology published by Galenos Publishing House. 


\section{Introduction}

Dementia is a disease with an insidious onset that progresses slowly and continuously over time. The clinical presentation according to changes in daily activities can vary from age-associated memory impairment, and mild cognitive impairment (MCI) to mild, moderate, and severe dementia stages (1). According to worldwide data, there were approximately 47 million patients with dementia as of 2014, and this number is expected to increase to 131 million by 2050 (2). The gradual increase in the elderly population causes physicians to encounter dementia more often. Considering the fact that $60-70 \%$ of dementia cases are due to Alzheimer's disease (AD), it is no surprise that the disease is one of the most important problems concerning public health and neurology (3).

Alzheimer-type dementia is the most common chronic neurodegenerative disease in the elderly population. The main features of neurodegenerative diseases are degeneration in the central nervous system (CNS) by the loss of neurons and synapses, selectively affecting one or more functional systems, and being progressive. Knowing their effects on different systems other than the CNS, which they affect primarily, will provide guidance for early diagnosis and treatment. Low uric acid (UA) concentrations is a risk factor for many neurodegenerative diseases (4).

UA is the last product of purine catabolism. It is converted to hypoxanthine and xanthine by the enzyme xanthine oxidase. Xanthine oxidase is usually found as xanthine dehydrogenase and xanthine oxidase holoenzyme. The dehydrogenase form produces UA and the nicotinamide adenine dinucleotide, and the oxidase form produces UA and superoxide. UA has been reported to cleanse toxic reactants at normal levels and protect against oxidative stress $(5,6)$.

A significant portion of studies researching the correlation between serum UA concentrations in patients with AD and healthy controls reported that UA values were lower in patients with $\operatorname{AD}(5,7,8,9,10,11)$. Additionally, there are studies reporting no significant relationship between $\mathrm{AD}$ and UA concentrations $(12,13)$.

The identification of oxidative stress-linked injury in the early stages and taking precautions to improve behavioral problems among patients with $\mathrm{AD}$ will make it possible to contribute to improving clinical outcomes and slowing progression. When the limitations of the disease-preventive effects of treatments applied after AD diagnosis is made are noted, identifying easily accessible biomarkers to ensure early diagnosis of the disease becomes important.

The aim of this study was to identify serum UA concentrations according to disease stage in patients with AD to collect data related to the hypothesis that oxidative stress is effective on the etiopathogenesis and progression of disease stage.

\section{Materials and Methods}

\section{Research Population and Sample}

The study sample consisted of 180 patients who were followed up and treated at Ordu University Training and Research Hospital and Ordu State Hospital neurology outpatient clinics, and 150 healthy patients who met the inclusion criteria within the same age range.

Patients who showed more than one cognitive disorder and were diagnosed with possible AD according to the diagnostic criteria of National Institute of Neurological and Communicative Disorders and Stroke-Alzheimer's Disease and Related Disorders Association were administered Clinical Dementia Rating Scale (CDR), Mini-Mental Test (MMSE), Geriatric Depression Rating Scale (GDRS), and whose dementia stages determined were included in our retrospective study (14).

The control group was composed of individuals within the same age range of patients with $\mathrm{AD}$ and whose neurological examinations were normal, MMSE scores above 24 points, GDRS scores below 11.

Patients who had diseases that might cause an increase in UA concentrations (e.g. gout, preeclampsia and eclampsia, pneumonia, leukemias, hemolytic anemias, pernicious anemia, lymphomas, polycythemias, kidney failure, hypoparathyroidism, ischemic heart disease, down syndrome, glycogen storage diseases, a-alpha lipoproteinemia type 3 hyperlipoproteinemia, lead poisoning) or diseases that might cause the detection of low values of UA (e.g. acute hepatitis, syndrome of inappropriate antidiuretic hormone secretion, Wilson's disease, acromegalia, Fanconi syndrome, and cancer), and who used antihypertensive medications that could affect UA concentrations (e.g. losartan, various diuretics, hydrochlorothiazide furosemide, ethacrynic acid), corticosteroids, alcohol, or tobacco were excluded from the study, in both the AD and control groups.

\section{Data Collection Tools}

Detailed neurologic examinations of all subjects in the patient and control groups were performed. In addition to demographic features, their chronic illnesses, past medical treatments, educational status, smoking/alcohol use histories were recorded. The MMSE and GDRS were performed in the patient and control groups. CDR staging was performed additionally in patients with a diagnosis of AD.

Venous blood samples for biochemical and hemogram studies were collected after 12-14 hours of fasting in the patient and control groups.

\section{The Clinical Dementia Rating Scale}

The CDR was developed by Hughes et al. (15) in 1982 to assess functional degeneration in patients with AD. Patients are assessed in terms of memory, orientation, judgment and problemsolving, community affairs, hobbies and personal care, and they are categorized into the following stages; 0 (no degeneration), 0.5 (mild cognitive impairment), 1 (mild dementia), 2 (moderate dementia), 3 (severe dementia).

\section{Standardized Mental State Examination}

The MMME was first published by Folstein et al. (16). The test is a short, convenient, and standardized method that can be used to determine the cognitive level globally. It comprises eleven items that are grouped under five main headings, namely orientation, recording memory, attention, calculation, recall and language, and is evaluated over a total score of 30 . The Turkish validity and reliability study was performed by Güngen et al. (17). In the validity and reliability study, the threshold value of 23/24 for the 
MMSE was found to possess very high sensitivity and specificity in the case of mild dementia diagnosis in the elderly Turkish population. In the inter-rater reliability study, r was 0.99 and the kappa value was 0.92 .

\section{Geriatric Depression Scale}

The GDRS was developed by Yesavage et al. (18) (1982) and its validity and reliability study was performed. It consists of 30 easy-to-answer questions based on self-reporting targeted towards the elderly. It only consists of "yes" or "no" questions, and does not contain any questions about symptoms that can occur due to non-depressive causes, primarily somatic symptoms such as sleep disorders, sexual dysfunction, and pain and sores in the body. Each response is worth one point in favor of depression, and the other answers are worth zero points. Scores of 0-10 are accepted as "no depression", 11-13 points as "possible depression", and 14 or more points as "definitive depression". In our country, the validity and reliability studies were performed by two different groups $(19,20)$.

\section{Collection of Samples and Obtaining Serum}

Blood samples for analysis were obtained from outpatients attending our hospital. Blood was taken from patients after nearly 12 hours fasting between 08:00 and 12:00 in the morning. Separator gel tubes were used to obtain serum and potassiumEDTA tubes were used for blood counts. Under appropriate laboratory conditions, separator gel tubes were left for 20 minutes and then centrifuged at $5000 \mathrm{rpm}$ for 10 minutes to separate the serum.

Albumin, C-reactive protein, and UA tests were studied in our laboratory using spectrophotometric measurement in a closed system using a Cobas 8000 series c702 modular analyzer.

Blood counts (hemograms) were collected from results obtained with an XN-1000 in our laboratory. This device is a closed-system analyzer that uses fluorescence flow cytometry for measurements in all modes.

\section{Ethical Considerations of the Research}

The study was approved by the resolution of Ordu Province General Secretariat of Public Hospitals Union and ethics committee of Ordu University Training and Research Hospital (Resolution number: 2018/166) to be conducted for the purpose of "Assessment of Serum Uric Acid Levels in Terms of Stages in Patients Diagnosed with Alzheimer's-type Dementia” at Ordu University Training and Research Hospital and Ordu State Hospital Neurology Outpatient Clinics.

\section{Statistical Analysis}

The SPSS 25.0 statistical analysis software package was used for the statistical analysis of the data. Continuous measurements are summarized as mean and standard deviation. In two-group comparisons of quantitative variables without normal distribution, the Mann-Whitney $U$ test was used, whereas in variables with normal distribution, the independent samples t-test was used. The Kruskal-Wallis test was used in triple-group numerical value comparisons for non-normal distributions. One-way analysis of variance was used for the normal distributions. Spearman's rho test was used for correlation comparisons. The level of statistical significance in all tests was taken as $\mathrm{p}<0.05$.

\section{Results}

In our study, the control group included 76 healthy women and the mean age was $74.75 \pm 5.61$ years. The MMSE and GDS scores, and urea, creatinine, albumin, and UA concentrations were found as $29.21 \pm 1.04,2.76 \pm 1.58,30.26 \pm 9.12,0.78 \pm 0.09,4.54 \pm 0.25$, and $4.75 \pm 0.69$, respectively. The AD group included 90 female patients and the mean age was $75.67 \pm 4.39$ years. The MMSE and GDS scores, and urea, creatinine, albumin, and UA concentrations were $13.97 \pm 5.31 ; 3.22 \pm 1.51 ; 31.07 \pm 8.9 ; 0.78 \pm 0.08 ; 4.25 \pm 0.34$; $3.89 \pm 0.63$ respectively. There was no significant difference in age, urea, creatinine levels of females in control and AD groups $(\mathrm{p}>0.05)$. The MMSE score, and serum albumin and UA values were statistically significantly lower and GDS score was higher in the AD group $(\mathrm{p}<0.05)$ (Table 1$)$.

In our study, the control group included 74 healthy men and the mean age was $73.81 \pm 5.31$ years. The MMSE and GDS scores, and urea, creatinine, albumin, and UA concentrations were $29.39 \pm 1.84 ; \quad 2.66 \pm 1.59 ; \quad 31.18 \pm 8.65 ; \quad 0.86 \pm 0.13 ; \quad 4.55 \pm 0.3$; $4.98 \pm 0.83$, respectively. The AD group included 90 male patients and the mean age was $74.49 \pm 4.83$ years. The MMSE and GDS scores, and urea, creatinine, albumin, and UA concentrations were $14.21 \pm 5.06 ; 2.42 \pm 1.48 ; 32.65 \pm 8.37 ; 0.85 \pm 0.11 ; 4.16 \pm 0.37$; $4.06 \pm 0.59$, respectively. There was no significant difference in age, and urea and creatinine concentrations of females in the control and AD groups $(\mathrm{p}>0.05)$. The MMSE score, and serum albumin and UA concentrations were found to be statistically significantly lower in the AD group ( $\mathrm{p}<0.05)$ (Table 1$)$.

There was a significant difference in terms of age, duration of illness, MMSE score, and UA concentrations in females in accordance with disease stages in the study. As the stages progressed, the age and duration of illness increased, and MMSE score and UA decreased $(\mathrm{p}<0.05)$. Age, duration of illness, MMSE score, and urea and UA concentrations were significantly different in males. As the stages progressed, age, disease duration, and urea concentrations increased, and MMSE score and UA values decreased $(\mathrm{p}<0.05)$ (Table 2$)$.

In the study, a statistically significant level of correlation was identified between serum UA and albumin concentrations in patients with $\mathrm{AD}$ with patient age, disease duration, disease stage, and MMSE scores. Negative correlations were observed for patient age, disease duration, and disease stage (CDR) with serum UA and albumin concentrations, and a positive correlation was observed with MMSE score $(\mathrm{p}<0.05)$. In other words, serum UA and albumin values reduced with the increase in patient age, disease duration, and disease stage, whereas serum UA and albumin concentrations increased with the increase in MMSE scores (Table 3).

\section{Discussion}

There are three basic hypotheses that are widely accepted among the mechanisms that make up AD. These are oxidative stress, inflammation, and mitochondrial dysfunction. Although $\mathrm{AD}$ is associated with numerous etiologic and pathophysiologic mechanisms, oxidative stress appears as an important component of the pathophysiologic process $(21,22,23,24,25,26,27,28,29$, 30). Homocysteine, UA, albumin, and bilirubin are described as laboratory parameters associated with oxidative stress (11). 


\begin{tabular}{|c|c|c|c|c|c|}
\hline \multirow[t]{2}{*}{ Sex } & \multicolumn{2}{|c|}{ Control } & \multicolumn{2}{|c|}{$\mathrm{AD}$} & \multirow[t]{2}{*}{$\mathrm{p}$ values } \\
\hline & $\mathrm{n}$ & Mean \pm SD & $\mathrm{n}$ & Mean \pm SD & \\
\hline Age & 76 & $74.75 \pm 5.61$ & 90 & $75.67 \pm 4.39$ & 0.250 \\
\hline MMSE & 76 & $29.21 \pm 1.04$ & 90 & $13.97 \pm 5.31$ & $<0.001$ \\
\hline Urea (mg/dL) & 76 & $30.26 \pm 9.12$ & 90 & $31.07 \pm 8.9$ & 0.563 \\
\hline Creatinine $(\mathrm{mg} / \mathrm{dL})$ & 76 & $0.78 \pm 0.09$ & 90 & $0.78 \pm 0.08$ & 0.774 \\
\hline Albumin $(\mathrm{g} / \mathrm{dL})$ & 76 & $4.54 \pm 0.25$ & 90 & $4.25 \pm 0.34$ & $<0.001$ \\
\hline Uric acid $(\mathrm{mg} / \mathrm{dL})$ & 76 & $4.75 \pm 0.69$ & 90 & $3.89 \pm 0.63$ & $<0.001$ \\
\hline \multicolumn{6}{|l|}{ Males } \\
\hline Urea (mg/dL) & 74 & $31.18 \pm 8.65$ & 90 & $32.65 \pm 8.37$ & 0.319 \\
\hline Creatinine $(\mathrm{mg} / \mathrm{dL})$ & 74 & $0.86 \pm 0.13$ & 90 & $0.85 \pm 0.11$ & 0.896 \\
\hline Albumin (g/dL) & 74 & $4.55 \pm 0.3$ & 90 & $4.16 \pm 0.37$ & $<0.001$ \\
\hline Uric acid (mg/dL) & 74 & $4.98 \pm 0.83$ & 90 & $4.06 \pm 0.59$ & $<0.001$ \\
\hline
\end{tabular}

Table 2. Data on the diagnosis of female and male Alzheimer-type dementia

\begin{tabular}{|c|c|c|c|c|c|c|c|}
\hline \multirow[t]{2}{*}{ Sex } & \multicolumn{2}{|c|}{ Stage 1} & \multicolumn{2}{|c|}{ Stage 2} & \multicolumn{2}{|c|}{ Stage 3} & \multirow[t]{2}{*}{$\mathrm{p}$ values } \\
\hline & $\mathrm{n}$ & Mean \pm SD & $\mathrm{n}$ & Mean \pm SD & $\mathrm{n}$ & Mean \pm SD & \\
\hline \multicolumn{8}{|l|}{ Females } \\
\hline Age & 28 & $72.5 \pm 3.77$ & 30 & $74.83 \pm 3.5$ & 32 & $79.22 \pm 2.97$ & $<0.001$ \\
\hline DD & 28 & $2.43 \pm 0.96$ & 30 & $6.37 \pm 1.19$ & 32 & $9.34 \pm 2.01$ & $<0.001$ \\
\hline MMSE & 28 & $20.5 \pm 1.2$ & 30 & $14.27 \pm 1.36$ & 32 & $7.97 \pm 1.47$ & $<0.001$ \\
\hline GDRS & 28 & $3 \pm 1.33$ & 30 & $3.6 \pm 1.63$ & 32 & $3.06 \pm 1.5$ & 0.257 \\
\hline Urea $(\mathrm{mg} / \mathrm{dL})$ & 28 & $29.78 \pm 9.72$ & 30 & $30.29 \pm 9.58$ & 32 & $32.94 \pm 7.31$ & 0.419 \\
\hline Creatinine $(\mathrm{mg} / \mathrm{dL})$ & 28 & $0.77 \pm 0.06$ & 30 & $0.78 \pm 0.09$ & 32 & $0.79 \pm 0.1$ & 0.104 \\
\hline Albumin $(\mathrm{g} / \mathrm{dL})$ & 28 & $4.29 \pm 0.27$ & 30 & $4.23 \pm 0.28$ & 32 & $4.23 \pm 0.44$ & 0.720 \\
\hline Uric acid (mg/dL) & 28 & $4.34 \pm 0.54$ & 30 & $3.83 \pm 0.54$ & 32 & $3.54 \pm 0.53$ & $<0.001$ \\
\hline \multicolumn{8}{|l|}{ Males } \\
\hline Age & 31 & $73.26 \pm 3$ & 30 & $75.2 \pm 2.54$ & 29 & $81.28 \pm 4.54$ & $<0.001$ \\
\hline DD & 31 & $2.68 \pm 1.33$ & 30 & $6.37 \pm 1.03$ & 29 & $10.76 \pm 3.4$ & $<0.001$ \\
\hline MMSE & 31 & $19.97 \pm 1.11$ & 30 & $14.2 \pm 1.3$ & 29 & $8.07 \pm 1.62$ & $<0.001$ \\
\hline GDRS & 31 & $2.74 \pm 1.46$ & 30 & $2.77 \pm 1.74$ & 29 & $2.72 \pm 0.92$ & 0.011 \\
\hline Urea (mg/dL) & 31 & $30.27 \pm 8.55$ & 30 & $32.38 \pm 8.48$ & 29 & $35.49 \pm 7.45$ & 0.027 \\
\hline Creatinine $(\mathrm{mg} / \mathrm{dL})$ & 31 & $0.87 \pm 0.11$ & 30 & $0.86 \pm 0.11$ & 29 & $0.82 \pm 0.11$ & 0.309 \\
\hline Albumin (g/dL) & 31 & $4.22 \pm 0.3$ & 30 & $4.21 \pm 0.31$ & 29 & $4.04 \pm 0.47$ & 0.097 \\
\hline Uric acid $(\mathrm{mg} / \mathrm{dL})$ & 31 & $4.47 \pm 0.54$ & 30 & $4.15 \pm 0.36$ & 29 & $3.54 \pm 0.45$ & $<0.001$ \\
\hline
\end{tabular}


Table 3. Correlation of Alzheimer-type dementia patient data with uric acid and albumin levels

\begin{tabular}{|lllll|} 
& \multicolumn{2}{c}{ Uric acid } & \multicolumn{2}{c|}{ Albumin } \\
Age & $\mathbf{R}$ & p-value & $\mathbf{R}$ & p value \\
MMSE & -0.193 & $<0.001$ & -0.24 & $<0.001$ \\
DD & 0.576 & $<0.001$ & 0.479 & $<0.001$ \\
CDR & -0.54 & $<0.001$ & -0.248 & 0.001 \\
$\begin{array}{l}\text { Statistical significance level p }<0.05 \\
\text { MMSE: Mini-Mental Stage Examination, DD: Disease } \\
\text { Dementia Rating Scale }\end{array}$ & -0.472 & $<0.001$ & -0.779 & $<0.001$ \\
\hline
\end{tabular}

Low UA concentration is a risk factor for many neurodegenerative diseases (4). In a study conducted by Cipriani et al. (31) in 2010, it was emphasized that there was a strong correlation between Parkinson's disease (PD) and serum UA concentrations, and serum UA concentrations were an important indicator as a biomarker in terms of PD risk and prognosis. In a similar study, it was reported that there was a significant relationship between PD and serum UA concentrations, and that decreased UA concentrations were associated with disease severity $(32,33)$.

As a result of previous studies, it is suggested that there is a relationship between $\mathrm{AD}$ and serum UA values. A significant portion of studies researching the correlation between serum UA concentrations in patients with $\mathrm{AD}$ and healthy controls have reported the UA values are lower in patients with AD $(5,7,8,9,10,11,14,34,35)$. Additionally, there are studies reporting no significant relationship between $\mathrm{AD}$ and UA concentrations $(12,13,36)$. Xue et al. (37) reported in their 2017 study including 58 patients with MCI and 57 healthy participants that low UA concentrations posed a risk for MCI. Some studies show that patients with higher serum UA concentrations have a significantly lesser risk of dementia $(11,38,39,40,41,42)$. In their 2016 study, Du et al. (43) found that high serum UA values have a significant correlation with a decrease in AD risk. Nevertheless, Ahlskog et al. (12) showed that there were no significant differences between the PD, AD, and healthy control groups in terms of serum UA concentrations. In some recent studies, values of serum UA were found to be significantly higher in patients with AD compared with the control group $(13,44,45)$. In our study, MMSE scores were found to be statistically significantly lower in the $\mathrm{AH}$ group than in the control group $(\mathrm{p}<0.05)$. Our data are in accordance with and similar to the literature on the comparison of serum UA and albumin concentrations in AD (11). In addition, it is observed in both males and females that age and duration of the disease increase, and MMSE scores and UA concentrations decrease in parallel with the progression of disease stages. The most important additions to the literature of our study are the determination of serum UA concentrations according to the stage of disease and the detection of the increase in serum UA values. In parallel with the progression of disease stage, age and disease duration increase and MMSE scores fall, we did not study the correlation of UA and albumin concentrations with age, disease duration, and MMSE score so as to avoid repetition.
The assessment of data from our control and AD groups according to sex is considered a positive aspect of our study. In the literature, a study reporting sex-specific serum UA changes reported that high serum homocysteine, cholesterol, and UA concentrations might be linked to low estradiol levels (13). Another study did not identify a significant correlation between serum UA concentrations and cognitive functions in females. In males, high serum UA concentrations were associated with reduced attention and visuospatial functions (46). In our study, we found no differences between the UA concentrations of the female and male participants in the AD and control groups.

\section{Study Limitations}

The most important limitation of our study is the fact that anthropometric (e.g. height, weight, waist, hip, calf and forearm circumference) demographic and nutritional characteristics, educational attitudes, regular exercise, and the possible effects of the drugs used were not assessed in the AD and control groups. The cross-sectional nature of our work limits our ability to identify any causality between variables. Additionally, the relatively small size of our sample and our lack of use of detailed neuropsychological tests are other significant limitations. Another limitation is that oxidative stress biomarkers such as bilirubin and homocysteine were not assessed within the scope of our study. As a result, there is a need for more comprehensive and broad population-based prospective studies to assess the correlation of $\mathrm{AD}$ and oxidative stress biomarkers such as serum UA concentrations primarily, along with bilirubin and homocysteine values.

\section{Conclusion}

The results of our study support the hypothesis that serum antioxidant concentrations decrease parallel to the development of the disease and increases in oxidative damage are directly related to AD.

For the identification of chronic progressive diseases such as $\mathrm{AD}$ and to take precautions, the identification of variations in easily accessible and low-cost parameters such as serum albumin and UA concentrations in the early stages becomes important. In future years, when neuroprotective and neuro-restorative treatment options are available, the identification of serum UA concentrations as a marker of disease progression and knowledge of the association between serum UA values and disease stage in our data will guide and support research into disease etiology.

\section{Ethics}

Ethics Committee Approval: The study were approved by the Ordu University Clinical Research of Local Ethics Committee (Protocol number: 2018/166).

Informed Consent: Retrospective study.

Peer-review: Externally and internally peer-reviewed.

\section{Authorship Contributions}

Concept: T.Y., H.O.Y., Design: T.Y., H.O.Y., Data Collection or Processing: T.Y., H.O.Y., Analysis or Interpretation: T.Y., H.O.Y., Literature Search: T.Y., H.O.Y., Writing: T.Y., H.O.Y.

Conflict of Interest: No conflict of interest was declared by the authors.

Financial Disclosure: The authors declared that this study received no financial support. 


\section{References}

1. Small GW, Gunay I. Geriatric Medicine. In: Rundel JR, Wise MG (eds). Textbook of Consultation-Liaison Psychiatry: Psychiatry in Medically Ill. Washington, American Psychiatric Press, 2005:878-899.

2. Prince MJ, James M, Comas-Herrara A, et al. Improving heathcare for people living with demantia: coverage, quality and costs now and in the future. World Alzheimer Report 2016. London: Alzheimer Disease International, 2016. 131p.

3. Koca E, Taşkapılıŏglu Ö, Bakar M. Caregiver Burden in Different Stages of Alzheimer's Disease. Noro Psikiyatr Ars 2017;54:82-86.

4. Schirinzi T, Lazzaro GD, Colona CL, et al. Assesment of serum uric acid as risk factor for tauopathies. J Neural Transm 2017;124:1105-1108.

5. Cankurtaran M, Yesil Y, Kuyumcu ME, et al. Altered levels of homocysteine and serum natural antioxidants links oxidative damage to Alzheimer's disease. J Alzheimers Dis 2013;33:1051-1058.

6. El Ridi R, Tallima H. Physiological functions and pathogenic potential of uric acid: A review. J Adv Res 2017;8;487-493.

7. Euser SM, Hofman A, Westendorp RG, Breteler MM. Serum uric acid and cognitive function and dementia. Brain 2009;132:377-382.

8. Polidori MC, Mecocci P. Plasma susceptibility to free radical-induced antioxidant consumption and lipid peroxidation is increased in very old subjects with Alzheimer disease. J Alzheimers Dis 2002;4:517-522.

9. Kim TS, Pae CU, Yoon SJ, et al. Decreased plasma antioxidants in patients with Alzheimer's disease. Int J Geriatr Psychiatry 2006;21:344-348.

10. Irizarry MC, Raman R, Schwarzschild MA, et al. Plasma urate and progression of mild cognitive impairment. Neurodegener Dis 2009;6:23-28.

11. Cascalheira JF, Joao SS, Pinhancos SS, et al. Serum homocysteine: interplay with other circulating and genetic factors in association to Alzheimer's type dementia. Clin Biochem Clin Biochem 2009;42:783-790.

12. Ahlskog JE, Uitti RJ, Low PA, et al. No evidence for systemic oxidant stress in Parkinson's or Alzheimer's disease. Mov Disord 1995;10:566-573.

13. Chen X, Guo X, Huang R, et al. Serum uric acid levels in patients with Alzheimer's Disease: A meta-aanalysis. PLoS One 2014;9:e94084.

14. McKhann G, Drachman D, Folstein M, et al. Clinical diagnosis of Alzheimer's disease: report of the NINCDS-ADRDA Work Group under the auspices of Department of Health and Human Services Task Force on Alzheimer's Disease. Neurology 1984;34:939-944.

15. Hughes CP, Berg L, Danziger WL, et al. A new clinical scale for the staging of dementia. Br J Psychiatry 1982;140:566-572.

16. Folstein MF, Folstein SE, McHugh PR. Mini-mental state. J Psychiat Research 1975;12:189-198.

17. Güngen C, Ertan T, Eker E, Yaşar Y, Engin F. Standardize Mini Mental Test'in Türk toplumunda hafif demans tanısında geçerlik ve güvenilirliği. Türk Psikiyatri Dergisi 2002;13:273-281.

18. Yesavage JA, Brink TL, Rose TL, et al. Development and validation of a geriatric depression screening scale: a preliminary report. J Psychiatr Res 1982-1983;17:37-49.

19. Ertan T, Eker E, Şar V. Geriatrik Depresyon Ölçeğinin Türk Yaşlı Nüfusunda Geçerlilik Ve Güvenilirliği. Nöropsikiyatri Arşivi 1997;34:62-71.

20. Sağduyu A. Yaşlılar için depresyon ölçeği: Hamilton depresyon ölç̧ăi ile karşılaştırmalı güvenilirlik ve geçerlilik çalışması. Türk Psikiyatri Dergisi1997;8:3-8.

21. Yan MH, Wang X, Zhu X. Mitochondrial defects and oxidative stress in Alzheimer disease and Parkinson disease. Free Radic Biol Med 2013;62:9010.

22. Lee HP, Pancholi N, Esposito L, et al. Early induction of oxidative stress in mouse model of Alzheimer disease with reduced mitochondrial superoxide dismutase activity. PLoS One 2012;7:e28033.

23. Clark TA, Lee HP, Rolston RK, et al. Oxidative Stress and its Implications for Future Treatments and Management of Alzheimer Disease. Int J Biomed Sci 2010;6:225-227.
24. Butterfield DA. Oxidative stress in Alzheimer disease: synergy between the Butterfield and Markesbery laboratories. Neuromolecular Med 2011;13:1922.

25. Gella A, Durany N. Oxidative stress in Alzheimer disease. Cell Adh Migr 2009;3:88-93.

26. Moreira PI, Siedlak SL, Aliev G, et al. Oxidative stress mechanisms and potential therapeutics in Alzheimer disease. J Neural Transm (Vienna) 2005;112:921-932.

27. Maiese K, Chong ZZ. Insights into oxidative stress and potential novel therapeutic targets for Alzheimer disease. Restor Neurol Neurosci 2004;22:87-104.

28. Mecocci P. Oxidative stress in mild cognitive impairment and Alzheimer disease: a continuum. J Alzheimers Dis 2004:159-163.

29. Christen Y. Oxidative stress and Alzheimer disease. Am J Clin Nutr 2000;71:621S-629S.

30. Huang W, Zhang X, Chen W. Role of oxidative stress in Alzheimer disease. Biomed Rep 2016;4:519-522.

31. Cipriani S, Chen X, Schwarzschild MA. Urate: a novel biomarker of Parkinson's disease risk, diagnosis and prognosis. Biomark Med 2010;4:701712.

32. Sakuta H, Suzuki K, Miyamoto T, et al. Serum uric acid levels in Parkinson's disease and related disorders. Brain Behav 2017;7:e00598.

33. Vieru E, Köksal A, Mutluay M, et al. The relation of serum uric acid levels with L-Dopa treatment and progression in patients with Parkinson's disease. Neurol Sci 2016;37:743-747.

34. Pu Z, Xu W, Lin Y, He J, Huang M. Oxidative Stress Markers and Metal Ions are Correlated With Cognitive Function in Alzheimer's Disease. Am J Alzheimers Dis Other Demen 2017;32:353-359.

35. Ye BS, Lee WW, Ham JH, et al; Alzheimer's Disease Neuroimaging Initiative. Does serum uric acid act as a modulator of cerebrospinal fluid Alzheimer's disease biomarker related cognitive decline? Eur J Neurol 2016;23:948-957.

36. Latourte A, Bardin T, Richette P. Uric acid and cognitive decline: a doubleedge sword? Curr Opin Rheumatol 2018;30:183-187.

37. Xue L, Liu Y, Xue H, et al. Low uric acid is a risk factor in mild cognitive impairment .Neuropsychiatr Dis Treat 2017:13;2363-2367.

38. Polidori MC, Mattioli P, Aldred S, et al. Plasma antioxidant status, immunoglobulin $\mathrm{g}$ oxidation and lipid peroxidation in demented patients: relevance to Alzheimer disease and vascular dementia. Dement Geriatr Cogn Disord 2004;18:265-270.

39. Zafrilla P, Mulero J, Xandri JM, et al. Oxidative stress in Alzheimer patients in different stages of the disease. Curr Med Chem 2006;13:1075-1083.

40. Carantoni M, Zuliani G, Munari MR, et al. Alzheimer disease and vascular dementia: relationships with fasting glucose and insulin levels. Dement Geriatr Cogn Disord 2000;11:176-180.

41. Maesaka JK, Wolf-Klein G, Piccione JM, Ma CM. Hypouricemia, abnormal renal tubular urate transport, and plasma natriuretic factor(s) in patients with Alzheimer's disease. J Am Geriatr Soc 1993;41:501-506.

42. Can M, Varlibas F, Guven B, Akhan O, Yuksel GA. Ischemia modified albumin and plasma oxidative stress markers in Alzheimer's disease. Eur Neurol 2013;69:377-380.

43. Du N, Xu D, Hou X, et al. Inverse association between serum uric acid levels and Alzheimer' disease risk. Mol Neurobiol 2016;53:2594-2599

44. Iuliano L, Monticolo R, Straface G, et al. Vitamin E and enzymatic/oxidative stress-driven oxysterols in amnestic mild cognitive impairment subtypes and Alzheimer's disease. J Alzheimers Dis 2010;21:1383-1392.

45. Cervellati C, Cremonini E, Bosi C, et al. Systemic oxidative stress in older patients with mild cognitive impairment or late onset Alzheimer's disease. Curr Alzheimer Res 2003;10:365-372.

46. Kueider AM, An Y, Tanaka T, et al. Sex-Dependent Associations of Serum Uric Acid with Brain Function During Aging. J Alzheimers Dis 2017;60:699-706 